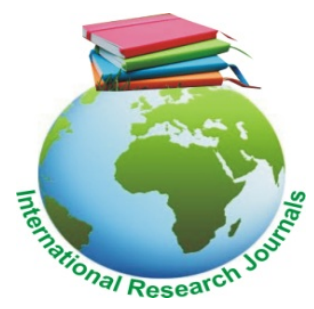

\title{
Moringa oleifera diet improves the toxic effects of palm wine and local gin on hematological and hemostatic parameters in albino rats
}

\author{
Okwari Obem Obo ${ }^{1}$, Kolawole Tolunigba Abisola ${ }^{2 *}$, Wali Catherine ${ }^{3}$, Oluwatayo Beatrice \\ Olatundun ${ }^{2}$, Okon Hannah ${ }^{1}$
}

${ }^{1}$ Department of Human Physiology, Faculty of Medical Sciences, Cross River University of Technology, Okuku, Cross River State, Nigeria.

${ }^{2}$ Department of Physiology, Faculty of Medical Sciences, Madonna University, Elele, Rivers State.

${ }^{3}$ Department of Anatomy, Faculty of Medical Sciences, Madonna University, Elele, Rivers State *Corresponding author's E-mail: tolueneok02@yahoo.com

\begin{abstract}
The effect of Moringa oleifera diet on the toxic effects of palm wine and local gin on hematological and hemostatic parameters in albino rats was determined in this research. Thirty female albino wistar rats were used for this study. The rats were aged 8 to 10 weeks and weighed between $170 \mathrm{~g}$ and $200 \mathrm{~g}$. They were divided into six groups: Groups 1 to 6 of 5 rats each. All the rats except the ones in group 1 were fed with $11.1 \%$ of Moringa oleifera diet. Group 1 served as the Control group; rats in this group were given normal rat chow, group 2 rats were given Moringa oleifera diet only, group 3 rats were given 10 $\mathrm{ml} / \mathrm{kg}$ bwt of palm wine only, group 4 rats were given $0.03 \mathrm{ml} / \mathrm{kg}$ bwt of local gin only, group 5rats were given $10 \mathrm{ml} / \mathrm{kg}$ bwt palm wine with Moringa oleifera diet and group 6 rats were given $0.03 \mathrm{ml} / \mathrm{kg}$ bwt of local gin with Moringa oleifera diet. Palm wine and local gin were administered to the rats daily using an oral cannula. All administrations were done for a total of 30 days. On the $31^{\text {st }}$ day, the rats were sacrificed and blood was collected through cardiac puncture for the determination of some hematological and hemostatic parameters. The results of this study showed that M.oleifera diet improved the hematological and hemostatic parameters of the rats that were adversely affected by palm wine and local gin.
\end{abstract}

Keywords: Moringa olifera, Palm wine, Local gin, Haematology, Hemostatic, Rats.

\section{INTRODUCTION}

Moringa oleifera, family Moringaceae is native to subHimalayan region, India, Pakistan, Asia Minor, Africa and Arabia (Farooq et. al., 2007). It is widely cultivated and has become naturalized in many parts of the tropics (Harbone, 1998). All parts of the plant: root, back, fruit, seed, leaf, pods have been reported to have medicinal, social, nutritional and industrial values (Silva et al.,1998). The plant contains protein, vitamins A, B complex (B1, B3, B6 and B7), C, D, E and K (Dorga and Tandon, 1975; Booth and Wickens, 1988; Vinodini et al., 2014), B- carotene, amino acids and various phenolics which confer its use in man's health challenges.

The plant has been reported to improve hematological parameters, be used in treating high blood pressure, diarrhea, inflammation of colon, intestinal worms, skin antiseptic, as a diuretic agent intestinal worms, diabetes, ulcer and promote immunity against infections, antipyretic and antidiarrhea (Lowell, 2002; Jaiswal et al., 2009; Chinwe and Isitua, 2010; Pal and Sahib, 1995;Trease and Evans, 2002). 
Palm wine also known as palm toddy or simply toddy is a milky alcoholic beverage obtained from the sap of the tropical plants of the Palmae family (Oyedeji et al., 2012). It is commonly called Emu by Yoruba ethnic group of Nigeria, Nsafufuo by the Ghanians and Tuba by the Mexicans.

It is widely consumed at homes in social events and during performance of some traditional rites. Palm wine (alcohol) consumption over a period of time contribute to impaired health.For example increased susceptibility to blood plasma protein malnutrition,multivitamin deficiencies,pre-mature death (Liang et al., 2000), deleterious effects on the reproductive functions of male albino wistar rats (Oyedeji et al., 2012) and could also cause prenatal osteo-inhibitory effects (Eluwa et al., 2010).

Local (illicit) gin (Ogogoro) is an alcoholic beverage prepared by the distillation of the fermented sap of Raphia palms (Raphia hookeri), coconut palm (cocusnucifera), and oil palm (Elaeis guinesis). The beverage local gin (Ogogoro) is popular in West Africa. In South America, it is referred to as toddy, in Ghana, it is known as Akpeteshi while in Nigeria it is known as illicit gin, local gin, kai-kai, ogogoro etc (Idonije et al., 2012). Local gin (Alcohol) has widespread direct and indirect effects on the hematologic system which can mimic and or obscure other disorders. Leukocyte, erythrocyte and thrombocyte production and functions are affected directly. Liver damage secondary to alcohol abuse also impacts red blood cells and the hemostatic mechanisms (Idonije et al., 2012). Nutritional deficiencies are caused not only by poor dietary habits practiced by alcohol abusers but by the effect of alcohol on the absorption, storage and utilization of several vitamins (Akanni et al., 2010).

The present study was undertaken to determine the possible beneficial effects of $M$ oleifera diet on the toxic effects of palm wine and local gin on hematological and hemostatic parameters in wistar rats.

\section{MATERIALS AND METHOD}

\section{Collection and preparation of leaves}

Fresh mature healthy and good quality of Moringa oleifera leaves were collected from a farm in Okuku Yala Local Government Area, Cross River State, Nigeria during the month of June,2014 The plant material was botanically identified and authenticated( Herbarium number:RUBL-20287) in the Department of Botany, Faculty of Basic Medical Sciences University of Calabar, Nigeria. The leaves were thoroughly washed, shade dried for 14 days. The leaves were turned over to prevent mould growth and heat buildup that may change leaf colour. The completely dried and crispy leaves were ground in a domestic corn mill into powder and stored in air tight container until they were ready to be used in the Moringa oleifera diet production.

\section{Preparation of moringa oleifera diet}

Standard rat pellet chow was used as control diet. The pellet was ground to facilitate the incorporation of Moringa oleifera leaf powder. Moringa oleifera supplemented feed was prepared by mixing $11.1 \%$ on weight basis of Moringa oleifera leaf powder to normal rat feed. Dried Moringa oleifera leaf powder was weighed and mixed with rat chow in the ratio $(1: 9, \mathrm{w} / \mathrm{w}$ respectively).

\section{Palm wine and local gin}

Fresh $50 \%$ diluted palm wine obtained from oil palm was collected on daily basis from a local palm wine seller in Okuku Yala Local Government Area, Cross River State, Nigeria. The palm wine was administered at dose of $10 \mathrm{ml} / \mathrm{kg}$-bwt (Oyedeji et al., 2012). The local gin was administered at dose of $0.03 \mathrm{ml} / \mathrm{kg}$ bwt (Okoroafor et al., 2013)

\section{Experimental design}

Thirty female albino rats were used for this study. The rats were aged 8 to10 weeks and weighed between 170 and $200 \mathrm{~g}$. They were divided into six groups: Groups 1 to 6 of 5 rats each. Rats in each group were placed in separate cages in the Animal House of Cross River State University of Technology, Nigeria under natural day and night cycles. The rats had free access to normal rat chow and tap water ad libitum.

They were allowed two weeks of acclimatization to their environment. The animals were subsequently treated as follows;

Group 1: Control; rats in this group were given $2 \mathrm{ml} / \mathrm{kg}$ bwt of distilled water.

Group 2: rats in this group were given Moringa oleifera diet only.

Group 3: rats in this group were given $10 \mathrm{ml} / \mathrm{kg}$ body weight of palm wine only without the Moringa oleifera diet.

Group 4: rats in this group were given $0.03 \mathrm{ml} / \mathrm{kg}$ body weight of local gin only without the Moringa oleifera diet.

Group 5: rats in this group were given palm wine $10 \mathrm{ml} / \mathrm{kg}$ bwt and Moringa oleifera diet.

Group 6: rats in this group were given local gin $(0.03 \mathrm{ml} / \mathrm{kg})$ and Moringa oleifera diet.

The palm wine and local gin were administered to the rats daily using an oral cannula. Administrations were done for a total of 30 days. 


\section{Haematological Analysis of blood samples}

\section{Haematological Measurements}

Blood samples were collected through cardiac puncture into sample bottles tubes coated with ethylene diamine tetra-acetic acid (EDTA). The samples were immediately analyzed for haematological parameters using automated Sysmex apparatus of the type 8999. The parameters included: Hemoglobin $(\mathrm{Hb})$, Mean Cell Volume (MCV), Red Blood Cell Count (RBC), White Blood Cell Count (WBC), Mean Cell Hemoglobin Concentration (MCHC), and Platelets (PLT). MCV and MCHC values were calculated.

\section{Determination of Platelet Count}

Blood sample was collected into vials. The whole blood was diluted with $1 \%$ ammonium oxalate solution. The blood was mixed thoroughly with the oxalate solution. The dilution was prepared using the leukocyte/platelet Unopette system. It was then left to stand (incubate) for 10 minutes to allow the erythrocytes to haemolyse. After the incubation period, the dilution was mounted on a haemocytometer. The cells were allowed to settle and were viewed under the microscope. The number of platelet was then calculated per $\mu \mathrm{L}\left(\times 10^{\wedge} 9 / \mathrm{L}\right)$ of blood.

\section{Determination of bleeding time}

This was determined using a modified Duke method (Ochei and Kolhatkar, 2000). The rat tail was punctured using disposable lancet, and the stop watch was started as soon as bleeding started. The puncture was dabbed with filter paper every 15 seconds until the paper was no longer stained red with blood. Bleeding time was then taken as the time when the blood stopped flowing from the punctured tail.

\section{Determination of clotting time (Lee-White Method)}

Blood was taken directly from the heart (to avoid contamination with tissue thromboplastin) $0.8 \mathrm{mls}$ from each rat. $0.2 \mathrm{mls}$ of blood was then delivered into four glass test-tubes that had previously been warmed and maintained at $37^{\circ} \mathrm{C}$ and the tubes were immediately placed in a $37^{\circ} \mathrm{C}$ water bath to mimic the temperature of the internal environment. The stop watch was started immediately the blood was delivered into the glass testtubes and the tubes were continually tilted at 40 -second intervals (until blood in them stopped flowing when tilted at angle of $90^{\circ}$ ), starting with the first, to see and note when the blood clotted. The clotting time was taken as the average of the times blood clotted in the four tubes.

\section{Determination of prothrombin time (PT)}

Blood was collected into sample vials containing $3.2 \%$ sodium citrate (as specified in the PT test kit used) in the ratio 1:9 with the blood sample. The blood was then centrifuged at $1000 \mathrm{~g}$ for 15 minutes to obtain platelet poor plasma. Thromboplastin PT-S was placed in the water bath at $37^{\circ} \mathrm{C} ; 0.1 \mathrm{ml}$ of test plasma was also put into a test-tube and placed in the water bath to prewarm to $37^{\circ} \mathrm{C}, 0.2 \mathrm{ml}$ of warmed thrmboplastin PT-S was then forcibly added to the test plasma and the stop watch was started. The tube was tilted repeatedly until a clot was formed and the time taken to form clot was noted. This was repeated for all samples. Particular precaution was taken to perform test within three hours of blood collection since the labile factor deteriorates quickly at room temperature.

\section{Statistical analysis}

The results were analyzed using one way analysis of variance (ANOVA) and expressed as mean \pm SEM. Data was further subjected to LSD Post hoc test and differences. The results were considered significant at $p$ values of less than 0.05 .

\section{RESULTS}

The result of hematological parameters in rats is shown in Table 1. The results show that there was significant decrease $(p<0.05)$ in the red blood cell of the rats in Group 3(Palm wine only Group), Group 4(Local gin only Group) and in Group 6(Local gin+Moringa Diet Group) rats when compared to Group 1(Control Group) rats.

White blood cell count was significantly increased $(p<0.05)$ in rats of Group 2 (Moringa diet Group), Group 3(Palm wine only Group), Group 4 (Local gin only Group), Group 5 (Palm wine +Moringa oleifera diet Group) and significantly reduced $(p<0.05)$ in Group 6 (Local gin +Moringa diet Group) rats when compared to Group 1 ( Control Group) rats. .

Hemoglobin concentration was significantly increased $(p<0.05)$ in Group2 (Moringa diet Group) and Group 5 (Palm wine + Moringa diet Group) rats while it was significantly $(p<0.05)$ reduced in Group 4(Local gin only Group) when compared to Group 1(Control Group) rats.

Significant increase $(p<0.05)$ was seen in the hematocrit levels of the rats in Groups 2 (Moringa diet Group) and Group 5(Palm wine + Moringa diet Group), while significant decrease $(p<0.05)$ was seen in Group 6(Local gin + Moringa diet Group) rats when compared to Group 1(Control Group) rats.

Mean corpuscular volume was observed to be significantly increased $(p<0.05)$ in all the Groups (Groups 2,3,4,5 and 6), likewise the Mean Corpuscular 
Table 1: Effect of M.oleifera on Red Blood Cell Counts (RBC), White Blood Cell Counts (WBC), Hemoglobin Concentration (Hb), Hematocrit (HCT), Mean Corpuscular Volume (MCV), Mean Corpuscular Hemoglobin (MCH), Mean Corpuscular Hemoglobin Concentration (MCHC) and Platelet Counts in rats treated with palm wine and local gin.

\begin{tabular}{|c|c|c|c|c|c|c|c|c|}
\hline GROUPS & RBCs $10^{6} / \mathrm{mm}^{3}$ & WBC $\times 10^{3} / \mathrm{mm}^{3}$ & $\mathrm{Hb}(\mathrm{g} / \mathrm{dl})$ & НСТ ( \%) & $\operatorname{MCV}\left(\mathrm{mm}^{3}\right)$ & $\mathrm{MCH}(\mathrm{pg})$ & $\mathrm{MCHC}(\%)$ & PLT $\times 10^{3} / \mathrm{mm}^{3}$ \\
\hline Group1: Control. & $7.67 \pm 0.3$ & $6.51 \pm 0.06$ & $13.23 \pm 0.04$ & $39.61 \pm 0.17$ & $51.00 \pm 0.37$ & $17.33 \pm 0.08$ & $29.60 \pm 3.27$ & $416.67 \pm 10.54$ \\
\hline $\begin{array}{l}\text { Group2: Moringa oleifera } \\
\text { diet only. }\end{array}$ & $7.86 \pm 0.08$ & $9.33 \pm 0.18^{*}$ & $14.55 \pm 0.17^{*}$ & $42.52 \pm 0.55^{*}$ & $55.42 \pm 0.20^{*}$ & $18.40 \pm 0.04^{*}$ & $33.92 \pm 0.08^{*}$ & $468.33 \pm 2.11^{*}$ \\
\hline Group3: & $7.22 \pm 0.03^{*}$ & $7.44 \pm 0.15^{\star}$ & $12.48 \pm 0.21$ & $38.52 \pm 0.31$ & $55.92 \pm 1.26^{*}$ & $19.90 \pm 0.44^{*}$ & $34.07 \pm 0.07^{*}$ & $306.33 \pm 2.32^{*}$ \\
\hline \multicolumn{9}{|l|}{ Palm wine only. } \\
\hline Group4: Local gin only. & $6.59 \pm 0.02^{*}$ & $8.48 \pm 0.03^{*}$ & $12.29 \pm 0.17^{*}$ & $38.10 \pm 0.32$ & $59.00 \pm 0.45^{*}$ & $20.13 \pm 0.67^{\star}$ & $33.67 \pm 0.84^{*}$ & $330.50 \pm 1.12^{*}$ \\
\hline $\begin{array}{l}\text { Group5: Palm wine } \\
\text { + Moringa oleifera diet. }\end{array}$ & $7.63 \pm 0.04$ & $8.14 \pm 0.11^{*}$ & $14.05 \pm 0.03^{*}$ & $42.03 \pm 0.34^{*}$ & $54.50 \pm 0.22^{*}$ & $17.50 \pm 0.22$ & $32.72 \pm 0.02$ & $492.33 \pm 28.82^{*}$ \\
\hline $\begin{array}{l}\text { Group6: Local gin + } \\
\text { Moringa oleifera diet. }\end{array}$ & $6.78 \pm 0.29^{*}$ & $5.44 \pm 0.11^{*}$ & $13.73 \pm 0.48$ & $36.91 \pm 0.94^{*}$ & $56.00 \pm 1.44^{*}$ & $19.65 \pm 0.27^{*}$ & $36.73 \pm 0.53^{*}$ & $466.67 \pm 1.67^{*}$ \\
\hline
\end{tabular}

Hemoglobin was significantly increased $(p<0.05)$ in all the Groups (Groups 2,3,4,5 and 6) when compared to Group 1 (Control Group) rats. Platelet count was significantly increased in Group 2 (Moringa diet Group), Group 5 (Palm wine + Moringa diet), and Group 6 (Local gin +Moringa diet Group) rats and significantly $(p<0.05)$ decreased in Group 3 (Palm wine only Group) and Group 4 (Local gin only Group) rats when compared to Group 1 (Control Group) rats.

\section{Bleeding time}

Figure 1 shows the effect of the Moringa oleifera diet on bleeding time of the rats exposed to palm wine and local gin. The oleifera diet decreased bleeding time in rats of the experimental group (Group 3 and Group 4) in comparison with the control group (Group 1). The analysis showed that this decrease was significant $(P<0.05)$ in groups 5 (Palm wine + Moringa diet) and Group 6 (Local gin + Moringa diet Group) when compared with the Group 1(Control Group) rats.

\section{Clotting time}

There was decrease in clotting time of Group 3 (Palm wine only Group), and Group 4 (Local gin only Group) when compared to control group (Group 1) as shown in Figure 2. The decrease was statistically significant $(P<0.05)$.

\section{Prothrombin time}

There was significant decrease $(p<0.05)$ in prothrombin time in Group 3(Palm wine Group) and Group 4 (Local gin Group) rats when compared to the Group 1(Control Group). The prothrombin time was significantly increased in Group 2 (Moringa diet Group) rats when compared to Group1 (Control Group) as shown in figure 3. Data are represented as Mean \pm S.E.M. ${ }^{*}$
Significant with respect to the control $(p<0.05)(n$ $=5$ in each group).

\section{DISCUSSION}

In this study, the effect of M.Oleifera feed was investigated on the hematological parameters and hemostatic status of albino rats exposed to palm wine and local gin.

Palm wine and local gin adversely affected some hematological parameters;red blood cell count $(\mathrm{RBC})$ and packed cell volume (PCV) or hematocrit. This is in support of works where it was reported that chronic alcohol (ethanol) consumption caused hypocellularity (decreased production of the erythrocytes, leucocytes and thrombocytes), this lead to anaemia, leucopenia, thrombocytopenia and their relative sequelae (Vatn, 2001; Latvala et al., 2004).

Chronic alcoholism has been linked to insufficient availability of iron and other vital 


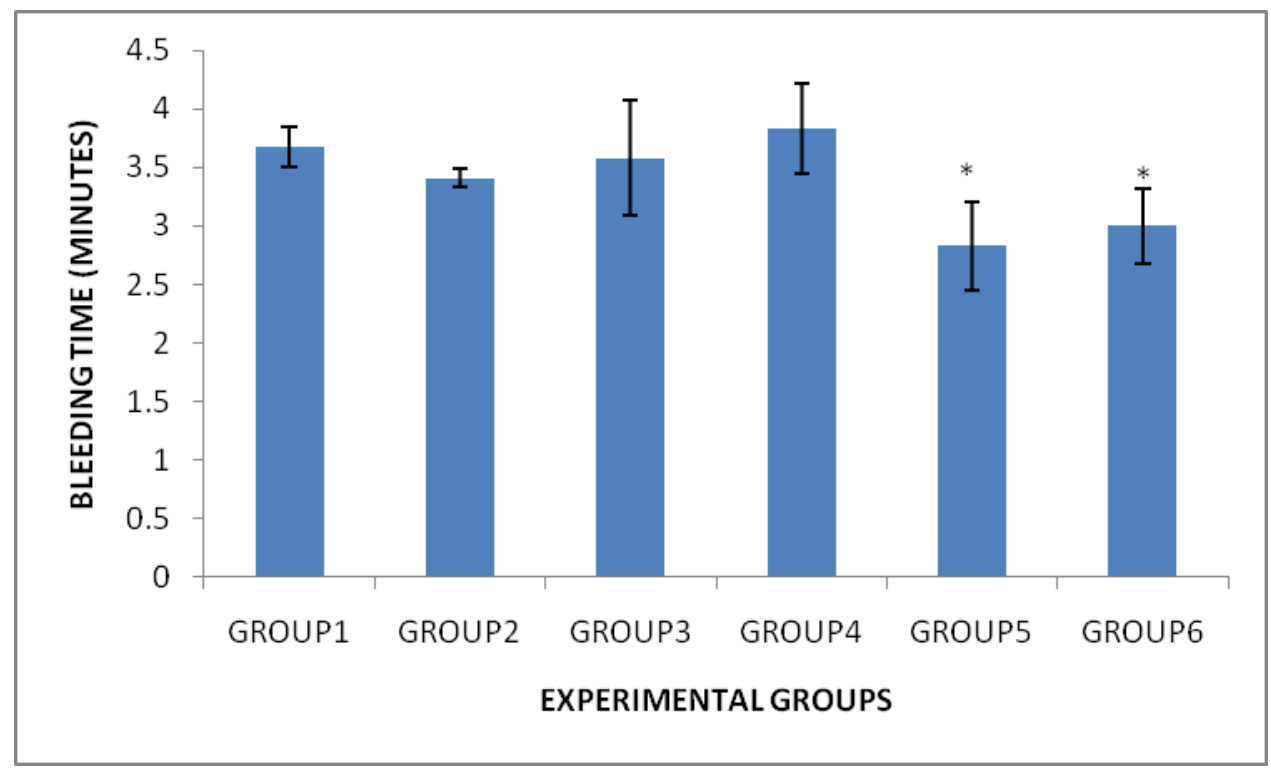

Figure 1: Changes in bleeding time in the groups. Values are expressed as mean \pm S.E.M. ${ }^{*} \mathrm{P}<0.05,(n=5)$

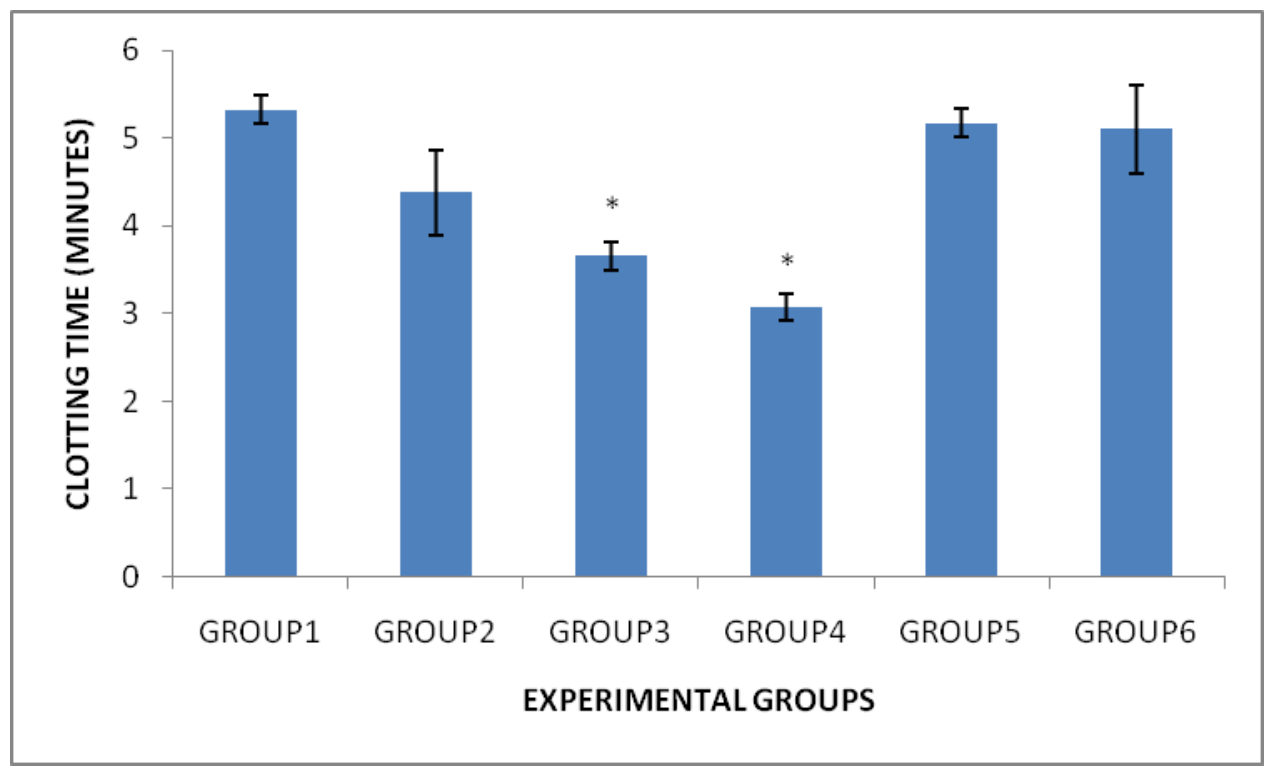

Figure 2: Changes in clotting time in the groups. Values are expressed as mean \pm S.E.M. ${ }^{*} \mathrm{P}<0.05,(n=5)$

Micro nutrients such as vitamin B12 and folate for erythropoietic activities (Heermans, 1998). This is due to the inability of the alcohol irritated sticky intestinal mucosa to absorb these essential blood forming components, which eventually result in impaired haemoglobin formation (the cause of hypochromic, microcytic anaemia) and defective DNA synthesis in the red cells which brings about megaloblastic anaemia. PCV otherwise known as haematocrit is a function of RBC concentration. It represents the percentage of RBC in blood (Kiraly, 1980). Therefore the decrease in PCV observed in this study is in agreement with the observed decrease in RBC counts.

Treatment of rats with alcohol may have adverse effect on the bone marrow, kidney and haemoglobin metabolism, since it has been reported that only substances which significantly affect the values of red blood cells and associated parameters would have 


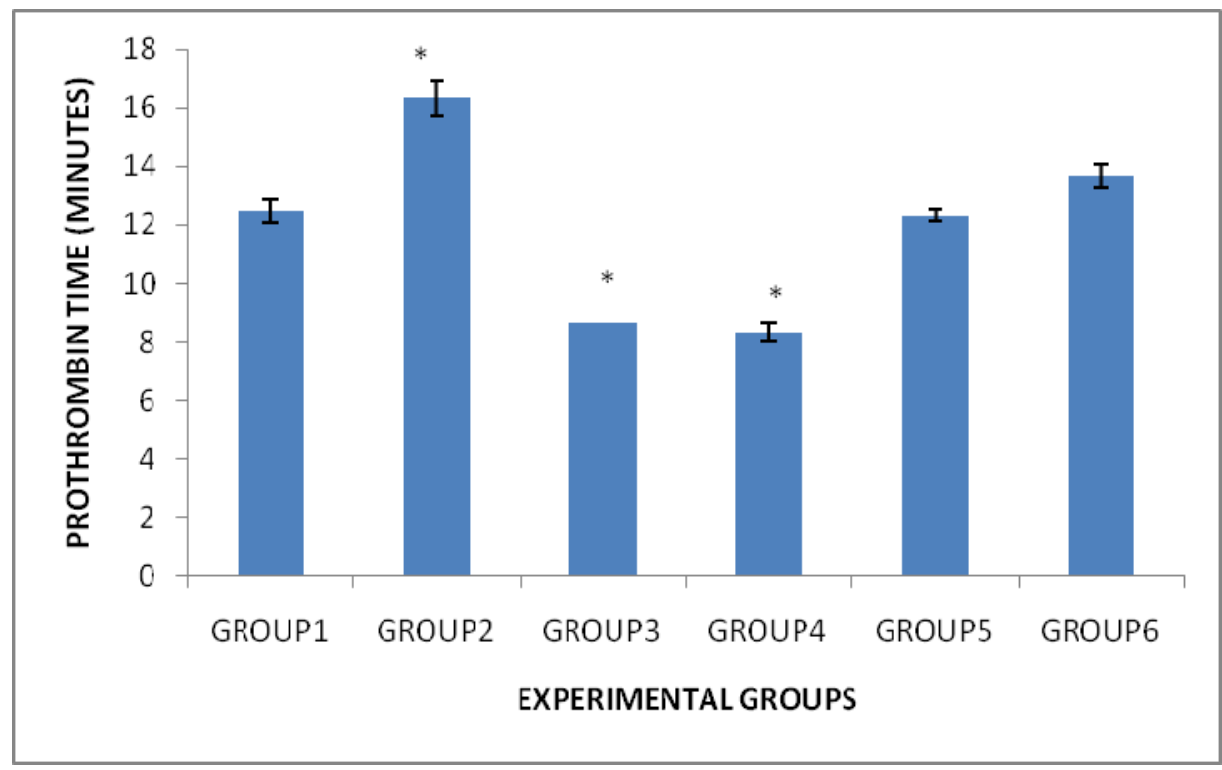

Figure 3: Changes in prothrombin time in the groups. Values are expressed as mean \pm S.E.M. * $P<0.05,(n=5)$

effects on the bone marrow, kidney and haemoglobin metabolism (Young and Maciejewski, 1997). This may account for the low level of hemoglobin observed in the present study.

The significant increase in white blood cell counts caused by palm wine and local gin probably may indicate the ability of the body to attack and destroy invading bacteria, viruses and other injurious agents (phagocytosis) has been enhanced. However, the observed increase in lymphocyte counts following exposure to alcohol may be one of the mechanisms used to defend the body against the toxic effect of alcohol (Akanni et al., 2010).

Palm wine and Local gin caused an increase in the Mean Cell Volume (MCV)and Mean Corpuscular Hemoglobin $(\mathrm{MCH})$ values which could be an indication of the presence of macrocytic anaemia since increased MCV and $\mathrm{MCH}$ values are known to be indicative of macrocytic anaemia (Fantozzi et al.,1986). This may be due to the fact that vitamin B12 and folate are poorly absorbed and/ or utilized in alcoholism during erythropoiesis as previously stated. Hence, the defects in RBC maturation with subsequent increase in the size of the RBC (macrocytosis), increased $\mathrm{MCV}$ and $\mathrm{MCH}$ (Fantozzi et al, 1986).

The increase in the Mean Corpuscular Hemoglobin Concentration(MCHC) value suggest the presence of hereditary spherocytosis since $\mathrm{MCHC}$ values are known to be elevated in hereditary spherocytosis (Oyedeji et al., 2013).

The observed decrease level of platelet counts in palm wine and local gin treated groups might be due to suppression of platelet production which probably led to thrombocytopenia. This condition may have occurred as a result of the cytotoxic effects of ethanol (Kristenson et al., 2008).

M.Oleifera diets however positively affect the hematological parameters of the rats given palm wine and local gin.

The mechanism of action of $M$. oleifera in building up red blood cell (RBC) may be attributed to its profile of important trace elements, proteins, vitamin (A, B and C), beta-carotene, amino acids, phenolics and iron (Amaglo et al., 2010).

Vitamin $C$ increases iron absorption in the animal's body (Anwar et al., 2007). Vitamin A is necessary for many functions in the ruminants including vision, bone growth, immunity and maintenance of epithelial tissue and maintains adequate levels of iron in plasma that supply the different body tissues including the bone marrow (Thurber and Fahey, 2009).

Iron, which is commonly deficient in many plant-based diets, was found in abundance in this plant's leaves. Iron is a necessary component of haemoglobin and myoglobin for oxygen transport and cellular processes of growth and division (Kozat, 2007).

In the present study, administration of M.oleifera diet effectively reduced bleeding time in the experimental rats in figure 1. Bleeding time is a sensitive test of endothelial and platelet function and platelet number (Cheesbrough, 2000). Thus the activity of the diet in decreasing bleeding time may result from an increase in platelet number. This can be seen in the results obtained from the platelet count which shows an increase in the platelet in the test groups. The platelet count increased effectively after administration of the diet. This could be as a result of the 
Vitamin $\mathrm{k}$ which has been shown to effectively increase platelet number (Ananyeva et. al., 2003) or vitamin C which is widely believed to also play a part in platelet number but without conclusive evidence.

From the results obtained, there was significant increase in clotting time, reflecting that there was an increase in one or more of the clotting factors involved in the intrinsic pathway. This can be traced to the presence of vitamin K. Moringa powder has been reported to be rich in vitamin K (Broin, 2006; Vinodini e .al., 2014). Vitamin $\mathrm{K}$ has been shown to stimulate liver production of factors II, IX and X (Stamatoyannopoulos, 2001).

The increase in prothrombin time by the diet may be as result of increase in the concentration of prothrombin or one of the other extrinsic clotting factors. Vitamin $\mathrm{K}$ has been shown to play a major role in essential the liver formation of the factors of the extrinsic pathway- factor prothrombin and factor X (Stamatoyannopoulos, 2001). This could therefore mean the presence of Vitamin $\mathrm{K}$ (Visalli et al., 1999) is responsible for the increased prothrombin time.

Tannin which is also present in M.oleifera leaf have been implicated in hemostatic activity of plants where they arrest bleeding from damaged or injured vessels by precipitating proteins to form vascular plugs (Bamidele et al., 2010) .

These aforementioned properties of Moringa oleifera leaves may have been responsible for the positive haemostatic activity of the diet, though other mechanisms may be responsible.

In conclusion, the M.oleifera diet supplementation had positive effects on the hematological and hemostatic parameters in albino rats treated with palm wine and local gin.

\section{REFERENCES}

Akanni EO, Mabayoje VO, Zakariyahu TO ,Oparinde DP (2010). Haematological Characterization among Heavy Alcohol Consumers in Osogbo Metropolis. Res J Med Sci .4(2);48-52.

Amaglo NK, Bennett RN, Lo Curto RB, Rosa EAS, Lo Turco V, Giuffrid A, Lo Curto A, Crea F, Timpo GM (2010). Profiling selected phytochemicals and nutrients in different tissues of the multipurpose tree Moringa oleifera Lam, grown in Ghana. Food Chemistry. 122(4):1047-1054.

Ananyeva NM, Saenko EL, Shima M (2003). The future of recombinant coagulation factors. J. Thromb. Haemost. 1:922

Anwar F,Latif S, Ashraf M, Gilani AH (2007). Moringa oleifera.a food plant with multiple medicinal uses. Phytother. Res.21(1):17-25.

Bamidele o,Akinnuga AM,Anyakudo MMC,Ojo OA,Ojo GB,Olorunfemi OJ,Johnson OP (2010). Hemostatic Effect of Methanolic Leaf Extract of Ageratum conyzoides in Albino Rats. J. Med. Plant Res. 4(20); 2075-2079.

Booth FE, Wickens GE (1988). Non-timber uses of selected arid zone trees and shrubs in Africa. FAO conservation guide.pp. 92-101.

Broin M (2006). The nutrient value of Moringa oleifera Lam. leaves.http://www.moringanews.org.

Cheesbrough M (2006). District laboratory practice in tropical countries. Cambridge University press, London.131-32.

Chinwe C, Isitua N ( 2010). Studies on the haematological impact of Moringa oleifera in rabbits. A poster presented at $2^{\text {nd }}$ Internationals
Conference on Applied Biotechnology, October 25-27, Khartoum, Sudan.

Dogra PD, Singh BP,Tandon S (1975). Vitamin content in Moringa. Curr. Sci , 44: $30-31$.

Eluwa MA, Agarrey LE, EkanemTB, Amabe OA, Agns OE, Ekong MB (2010).Comparative study of teratogenic effects of brewed beer and palm wine on fetal femur bone of albino Wistar rats. Int. J. Biomed. Health Sci.,6: 229-233.

Fantozzi R, Caramelli L, Ledda F, Moroni F, Masini E, Blandina P, Bolli P, Pcruzzi S,Zorn AM, Mannai-oni PF (1986). Biological Markers and Therapeutic Outcome in Alcoholic disease: A Twelve-year Survey. Department of preclinical and Clinical Pharmarcology, University of Florence, Italy, Toxicological unit, Florence University, School of medicine, Italy. Klin Wochensche. 7-33.

Farooq A,Sajid L,Muhammad A,Anwarul HG (2007). Moringa oleifera:a food plant with multiple medicinal uses. Phytotherapy Res. 21:1725.

Harbone TE (1998). Phytochemical Methods. A Guide to Modern Techniques of Plant Analysis, London Chapman and Hills, p 235.

Heermans EH (1998). Booze and Blood:the effects of acute and chronic alcohol abuse on the haematopoietic system. Clin Lab Sci.11(4): 229-32.

Idonije OB, Festus OO, Asika EC, llegbusi MI, Okhiai O (2012). A Comparative Biochemical Analysis of Local Gin (Ogogoro) from Different Parts of Nigeria and Imported Gin (Dry Gin) - Toxicogenic, Carcinogenic and Sociopolitical Implications. Sci J Med Clin Trials.2012:1-4

Jaiswal D, Kumar Rai P, Kumar A, Mehta S, Watal G (2009). Effect of Moringa oleifera Lam. leaves aqueous extract therapy on hyperglycemic rats. J Ethnopharmacol., 123(3):392-6.

Kiraly DA (1980). Haematology problem.Am J. Med. Tech 80: 25-27.

Kozat S (2007). Serum T3 and T4 concetrations in lambs with nutritional myodegeneration. J. Vet. Intern. Med., 21(5): 1135-7.

Kristensson- Aas A, Wallerstedt S, Alling C, Cederblad G, Magnusson B (1986). Haematological findings in clinical alcoholics after heavy drinking with specific reference to haemolysis.Eur. J. Clin. Invest.16(2):178-83.

Latvala J, Parkkila S, Niemela O (2004).Excess alcohol consumption is common in patients with cytopenia: Studies in blood and bone marrow cells. Diagnosis and treatment alcoholism. Clin. Exp. Res. 28: 619-924.

Liang TJ, Rehermann B, Seeff LB, Hoofnagle JH (2000).Pathogenesis, natural history,treatment and prevention of hepatitis C. Ann. Intern. Med.132(4);296-305.

Lowell J Fuglie (2002). The Miracle Tree. ACP - EU, Dakar. Pp 137139.

Ochei J, Kolhatkar A (2000) Medicinal Laboratory Science. Theory and Practise. Tata Mcgraw-Hill Pubishing Company Limited: New Delhi 2nd Edition. PP 331-349.

Okoroafor C, Ogbo I, Azi S (2013). The effect of alcohol intoxications on hematological parameters of adult albino wistar rats.Int $\mathrm{J}$ Comm Res.2(3);46-49

Oyedeji KO, Bolarinwa AF, Fashina AM (2013).Effect of Alcohol Consumption on Haematological and Reproductive Parameters in Female Albino Rats. J Dental and Med. Sci.3(5): 76-79.

Oyedeji KO, Bolarinwa AF, Hamzat MA (2012). Effect of Palm Wine on Reproductive Functions in Male Albino Wistar Rats.Res J Biol Sci. 7(9-12):340-344.

Pal SM, Sahib P (1995). Studies on anti ulcer activity of M.oleifera leaves extract on gastric ulcer models in rats. J Phytotherpy Res, 9:463 - 465 .

Saleem R (1995). Study of Chemical Constituents of Moringa Oleifera Lam. Ph.D. thesis, University of Karachi, Karachi.

Silva LG, LeeID S, Kinghorn A (1998).Special problem with extraction of plants In: Methods in Biotechnology natural products isolation Cannell JPR ed. Humana Press Inc. Totowa, New Jessey U.S.A 4:329-363.

Stamatoyannopoulos G (2001). The Molecular Basis of Blood Disease, 3rd ed. WB Saunders.

Thurber MD, Fahey JW (2009). Adoption of Moringa oleifera to combat under-nutrition viewed through the lens of the "Diffusion of innovations" theory. Ecol Food Nutr. 48(3): $212-25$. 
Trease and Evans (2002). Phamacognosy.15thEdition. Elsevier (A Divisionof Reed Elsevier India Pvt. Limited), pp 176 - 180.

Vatn MH (1974). The effect of Pentagastrin exogenous secretin and cholecystokinin (CCK)on the intrinsic factor (IF)secretion in man. J. Gastroenterol. Suppl. 29:53-6.

Vinodini NA, Pratik C, Anwar A, Suman VB, Sheila RP (2014). Evaluation of Liver Functions with Moringa oleifera leaf extract in Cadmium Induced Adult Wistar Albino Rats. Int J Plant, animal and environ sci.4(3);103-106.

Visalli N,Cavallo MG,Signore A,Baroni MG,Buzzetti R,Fioriti E,Mesturio C,Fiori R,Lucentini L,Matteoli MC,Crino A,Corbi S,Spera S,Teodino C,Paci F,Amoretti R,Pisano L, Suraci C,Multari G,Sulli N,Cervoni M,De Mattia G,Faldetta MR,Boscherini B,Pozzilli,P et al.(1999).Vitamin $E$ and nicotinamide have similar effects in maintaining residual beta cell function in recent onset insulin dependent diabetes.Diabetes Metab Res Rev 15(3);181-5

Young NS, Maciejewski J (1997). The pathphysiology of acquired aplastic anemia. N Engl. J. Med. 336(19):1365-72. 